\title{
A AVERBAÇÃO DE RESERVA LEGAL NO ATUAL CÓDIGO FLORESTAL (LEI Nº 12.651/2012): UMA ANÁLISE DA JURISPRUDÊNCIA MINEIRA
}

\author{
Michelle Lucas Cardoso Balbino ${ }^{1}$ \\ Simone Letícia Severo e Sousa ${ }^{2}$
}

Resumo: Com o advento do atual Código Florestal há divergência acerca da obrigatoriedade da averbação da reserva legal no Cartório de Registro de Imóveis. Uma corrente entende que a nova legislação ambiental não extinguiu a obrigação de averbação da reserva legal, já a outra, parte do pressuposto que constitui mera faculdade do proprietário a averbação perante o Cartório de Registro de Imóveis, não podendo ser imposta coercitivamente pela via judicial. Assim, este artigo realizou análise dos posicionamentos existente no Tribunal de Justiça de Minas Gerais (TJMG).

Palavras-Chave: Reserva Legal; Código Florestal; Averbação; Registro de Imóveis; Cadastro Ambiental Rural - CAR.

\section{THE REGISTRATION OF LEGAL RESERVES IN THE CURRENT FOREST CODE (LAW NR. 12,651/2012): AN ANALYSIS OF MINAS GERAIS'S JURISPRUDENCE}

\begin{abstract}
With the advent of the current forest code, divergences among the obligation regarding the registration of legal reserves in the Land Registry office have been established. While some doctrines understand that the new forest legislation did not extinguish the obligation to register legal reserves, others claim that it merely gives the owners the option to register their properties in the Land Registry office, which means that the registration should not be enforced by court. Thus, this article did an analysis of the several points of view existed in the Minas Gerais's Court of Justice, TJMG.
\end{abstract}

Keywords: Legal Reserve; Forest Code; Registration; Land Registration; Environment Rural Registry - CAR.

\footnotetext{
${ }^{1}$ Doutoranda em Direito pelo Centro Universitário de Brasília (UniCEUB/Brasília). Mestre em Sustentabilidade Socioeconômico e Ambiental pela Universidade Federal de Ouro Preto (UFOP/Ouro Preto). Professora e Coordenadora do Curso de Direito da Faculdade de Ciências e Tecnologias de Unaí (Factu/Unaí). E-mail: michellebalbino@hotmail.com

2 Doutora em Direito Público (PUCMinas/Belo Horizonte). Mestre em Direito das relações econômicoempresariais (Unifran/São Paulo). Coordenadora do Curso de Direito da Universidade José do Rosário Velano (Unifenas/Belo Horizonte). Professora Universitária. Assessora Judiciária - TJMG. E-mail: simoneleticia77@gmail.com
}

Rev. de Direito Ambiental e Socioambientalismo | e-ISSN: 2525-9628 | Maranhão | v. 3 | n. 2 | p. 1 - 21 | Jul/Dez. 2017 


\section{INTRODUÇÃO}

A Constituição Federal de 1988 trouxe maior relevância ao meio ambiente. O art. 225 da Constituição Federal trata do meio ambiente como direito fundamental, salientando que cabe ao Poder Público e à sociedade protegê-lo e preservá-lo. E em consonância com o art. 186, incisos I e II da Constituição Federal que apontam o aproveitamento adequado e racional dos recursos naturais como sendo um dos requisitos para a garantia da função social.

A reserva legal, instituto jurídico ambiental que define o centro deste trabalho, é imposta por lei ao proprietário de imóvel rural, de não explorar ou explorar de forma limitada parte de seu imóvel, tendo em vista a finalidade de preservação do meio ambiente. A função ecológica da reserva legal vem sofrendo alterações desde a Lei n. 4.771/1965, sendo hoje normatizada pela Lei Federal n. 12.651/2012 (atual Código Florestal). Em seu art. $3^{\circ}$, inciso III o Código Florestal conceitua reserva legal como sendo "área localizada no interior de uma propriedade ou posse rural" que visa "assegurar o uso econômico de modo sustentável dos recursos naturais do imóvel rural, auxiliar a conservação e a reabilitação dos processos ecológicos e promover a conservação da biodiversidade, bem como o abrigo e a proteção de fauna silvestre e da flora nativa" (BRASIL, 2012). Desse modo, evidencia-se que a reserva legal constitui um dos mais importantes temas da Legislação Ambiental Brasileira, para conservação da fauna, flora, dos processos ecológicos e a recuperação de áreas naturais.

O Atual Código Florestal (Lei n. 12.651/2012) provocou alterações no sistema de proteção e controle da área da reserva legal das propriedades rurais, promovendo consistente modificação na forma de realização do seu registro junto aos órgãos competentes. Tal fato está disposto tanto no caput do art. 18 da atual lei quando aponta que "A área de Reserva Legal deverá ser registrada no órgão ambiental competente por meio de inscrição no CAR...", como no $\S 4^{\circ}$ do mesmo artigo que aponta que "o registro da Reserva Legal no CAR desobriga a averbação no Cartório de Registro de Imóveis, sendo que, no período entre a data da publicação desta Lei e o registro no CAR, o proprietário ou possuidor rural que desejar fazer a averbação terá direito à gratuidade deste ato" (BRASIL, 2012).

Essa alteração legislativa fez nascer uma das maiores discussões existentes nos tribunais e na doutrina em matéria ambiental na atualidade, qual seja, a obrigatoriedade ou faculdade na averbação de reserva legal, tento em vista a vigência do atual Código Florestal. Essa discussão está presente no Tribunal de Justiça de Minas Gerais, sendo este o campo de pesquisa para a análise do problema aqui exposto. Assim, o presente trabalho tem o objetivo 
geral de analisar os posicionamentos adotados nos recentes julgados do Tribunal de Justiça de Minas Gerais (TJMG) quanto à obrigatoriedade ou faculdade de averbação de reversa legal, após o advento do atual Código Florestal (Lei n. 12.651/2012). O tema vem gerando polêmicas e discussões quanto qual posicionamento adotar, assim esse trabalho visa realizar uma reflexão jurídica dos posicionamentos adotados e inter-relacionar estes posicionamentos com as doutrinas ambientais existentes.

O presente trabalho foi realizado através de pesquisa qualitativa, com fonte secundárias para a definição do levantamento doutrinário necessário e técnica de pesquisa jurisprudencial para a elaboração dos posicionamentos e argumentos apresentados ao longo do presente trabalho. Ele está dividido em 04 (quatro) partes, a primeira analisando as alterações trazidas pelo atual Código Florestal acerca da averbação de reserva legal, a segunda apresentando os argumentos existentes nos posicionamentos jurídicos existentes no tribunal pesquisado, a terceira na definição da superação do princípio da proibição de retrocesso ambiental como base argumentativa da tese jurídica da obrigatoriedade de averbação de reserva legal e, por fim, a quarta parte definindo a tese jurídica da faculdade de averbação de reserva legal como tese mais viável.

\section{DAS ALTERAÇÕES TRAZIDAS PELO ATUAL CÓDIGO FLORESTAL ACERCA DA AVERBAÇÃO DE RESERVA LEGAL}

Para que se possa fazer uma análise completa dos posicionamentos relacionados ao tema averbação de reserva legal é imprescindível verificar como o tema se comportava nas legislações anteriores e como ele está definido na atuação norma, sendo este o objetivo deste tópico.

A averbação de área de preservação nos imóveis rurais foi instituída pela Lei n. 4.771, de 15 de setembro de 1965, com as modificações trazidas pela Lei n. 7.803, de 18 de julho de 1989, que em seu art. 16 aponta que:

\footnotetext{
Art. 16. As florestas de domínio privado, não sujeitas ao regime de utilização limitada e ressalvadas as de preservação permanente, previstas nos artigos $2^{\circ}$ e $3^{\circ}$ desta lei, são suscetíveis de exploração, obedecidas as seguintes restrições:

[...] $\S 2^{\circ}$ A reserva legal, assim entendida a área de, no mínimo, 20\% (vinte por cento) de cada propriedade, onde não é permitido o corte raso, deverá ser averbada à margem da inscrição de matrícula do imóvel, no registro de imóveis competente, sendo vedada, a alteração de sua destinação, nos casos de transmissão, a qualquer título, ou de desmembramento da área.
}

Rev. de Direito Ambiental e Socioambientalismo | e-ISSN: 2525-9628 | Maranhão | v. 3 | n. 2 | p. 1 - 21 | Jul/Dez. 2017 
Observa-se que a legislação acima, desde o início já definia a reserva legal como sendo uma restrição ao uso da propriedade privada, obrigando sua averbação a margem da matrícula do imóvel. A Lei n. 14.309/2002 traz o conceito de reserva legal:

\begin{abstract}
Art. 14 - Considera-se reserva legal a área localizada no interior de uma propriedade ou posse rural, ressalvada a de preservação permanente, representativa do ambiente natural da região e necessária ao uso sustentável dos recursos naturais, à conservação e reabilitação dos processos ecológicos, à conservação da biodiversidade e ao abrigo e proteção da fauna e flora nativas, equivalente a, no mínimo, $20 \%$ (vinte por cento) da área total da propriedade.

$\S 1^{\circ}$ - A implantação da área de reserva legal compatibilizará a conservação dos recursos naturais e o uso econômico da propriedade.

$\S 2^{\circ}$ - Fica condicionada à autorização do órgão competente a intervenção em área de reserva legal com cobertura vegetal nativa, onde não serão permitidos o corte raso, a alteração do uso do solo e a exploração com fins comerciais, ressalvados os casos de sistemas agroflorestais e o de ecoturismo.

$\S 3^{\circ}$ - A autorização a que se refere o $\S 2^{\circ}$ somente será concedida em área de proteção ambiental mediante previsão no plano de manejo.

$\S 4^{\circ}$ - A área destinada à composição de reserva legal poderá ser agrupada em uma só porção em condomínio ou em comum entre os adquirentes (Grifo).
\end{abstract}

Observa-se que a lei acima destaca o objetivo central da reserva legal, ao apontar a manutenção da qualidade ambiental dos imóveis. Este ponto também foi sustentado no art. 44 do Código Florestal de 2001, que assim previa:

\begin{abstract}
Art. 44. O proprietário ou possuidor de imóvel rural com área de floresta nativa, natural, primitiva ou regenerada ou outra forma de vegetação nativa em extensão inferior ao estabelecido nos incisos I, II, III e IV do art. 16, ressalvado o disposto nos seus $\S \S 5^{\circ}$ e $6^{\circ}$, deve adotar as seguintes alternativas isoladas ou conjuntamente:

I - recompor a reserva legal de sua propriedade mediante o plantio, a cada três anos, de no mínimo $1 / 10$ da área total necessária à sua complementação, com espécies nativas, de acordo com critérios estabelecidos pelo órgão ambiental estadual competente;

II - conduzir a regeneração natural da reserva legal;

III - compensar a reserva legal por outra área equivalente em importância ecológica e extensão, desde que pertença ao mesmo ecossistema e esteja localizada na mesma microbacia, conforme critérios estabelecidos em regulamento.
\end{abstract}

Observa-se que a reserva legal, conforme definia as normas acima, impunha aos proprietários a obrigação de proteção e recomposição das áreas para manutenção do ecossistema, definindo o mínimo de $20 \%$ por propriedade. Assim, a reserva legal busca como um todo a preservação do meio ambiente. Luís Carlos Silva de Moraes (2002, p. 30) ensina que reserva legal "não possui função vinculada ao imóvel especificamente, sendo limitação de nível macro, ou seja, mais preocupada com a melhoria regional da biodiversidade, do que propriamente com o ecossistema interno da propriedade".

Rev. de Direito Ambiental e Socioambientalismo | e-ISSN: 2525-9628 | Maranhão | v. 3 | n. 2 | p. 1 - 21 | Jul/Dez. 2017 


\section{A AVERBAÇÃO DE RESERVA LEGAL NO ATUAL CÓDIGO FLORESTAL (LEI № 12.651/2012): UMA ANÁLISE DA JURISPRUDÊNCIA MINEIRA}

A lei deu um caráter de relativa permanência à área florestada do país. A lei federal determina a imutabilidade da destinação da Reserva Legal Florestal de domínio privado, por vontade do proprietário. Nos casos de transmissão por compra e venda como, também, por acessão, usucapião e pelo direito hereditário, a área da Reserva, a partir da promulgação da Lei 7.803/1989, continua com os novos proprietários numa cadeia infinita. O proprietário pode mudar, mas não muda a destinação da área da Reserva Legal Florestal. ${ }^{3}$ (MACHADO, 2004, p. 722)

Luís Paulo Servinskas complementa:

Considera-se reserva legal a área localizada no interior de uma propriedade ou posse rural, delimitada nos termos do art. 12 da Lei n. 12.651-2012, com a função de assegurar o uso econômico de modo sustentável dos recursos naturais do imóvel rural, auxiliar a conservação e a reabilitação dos processos ecológicos e promover a conservação da biodiversidade, bem como o abrigo e a proteção da fauna silvestre e a flora nativa (art. $3^{\circ}$ da citada lei). (SERVINSKAS, 2014, p. 570)

A reserva legal é uma obrigação que recai diretamente sobre o proprietário do imóvel, independentemente de sua pessoa ou da forma pela qual tenha adquirido a propriedade; desta forma, ela está umbilicalmente ligada à própria coisa, permanecendo aderida ao bem. $\mathrm{O}$ proprietário, para se desonerar da obrigação, necessita, apenas, renunciar ao direito real que possui, mediante a utilização de qualquer uma das formas legais aptas para transferir a propriedade. (ANTUNES, 2010, p. 542-543).

Acerca do tema, ressalta Edis Milaré:

Reserva legal é uma limitação inerente ao atendimento de função social no exercício do direito de propriedade rural, reconhecida pela Carta Constitucional de 1988, independente de vegetação ali existente (natural, primitiva, regenerada ou plantada) ou do fato de essa vegetação ter sido substituída por outro uso do solo. Essa a intenção do Código Florestal de 1965, que ainda persiste. (MILARÉ, 2011, p. 996)

Trata-se de uma limitação administrativa imposta pelo Estado ao particular e ao direito de propriedade. Sobre o tema, ensina Hely Lopes Meirelles (2008, p. 639):

[...] é toda imposição geral, gratuita, unilateral e de ordem pública condicionadora do exercício de direitos ou de atividades particulares às exigências do bem-estar social." [...] as limitações administrativas hão de corresponder às justas exigências do interesse

\footnotetext{
${ }^{3}$ No mesmo sentido, após a adoção da Lei Federal 12.651/2012, cf. a opinião do mesmo Autor na seguinte obra: MILARÉ, Edis; MACHADO, Paulo Affonso Leme. Novo código florestal; comentários à Lei 12.651, de 25 de maio de 2012 e à MedProv 571, de 25 de maio de 2012. São Paulo: Revista dos Tribunais, 2012, p. 217-218.
}

Rev. de Direito Ambiental e Socioambientalismo | e-ISSN: 2525-9628 | Maranhão | v. 3 | n. 2 | p. 1 - 21 | Jul/Dez. 2017 
público que as motiva, sem produzir um total aniquilamento da propriedade ou das atividades reguladas. (...) Só são legítimas quando representam razoáveis medidas de condicionamento do uso da propriedade, em benefício do bem-estar social (CF, art. 170, III) e não impedem a utilização da coisa segundo sua destinação natural.

Celso Sptzcovsky (2008, p. 512/513) conceitua o instituto da limitação administrativa como sendo "um meio de intervenção na propriedade que traz restrições quanto ao uso, sem perda da posse, por meio de uma imposição geral, gratuita e unilateral”. Neste aspecto Maria Sylvia Zanella Di Pietro aponta que:

As limitações podem, portanto, ser definidas como medidas de caráter geral, impostas com fundamento no poder de polícia do Estado, gerando para os proprietários obrigações positivas ou negativas, com o fim de condicionar o exercício do direito de propriedade ao bem-estar social. (DI PIETRO, 1997, p. 131)

Sérgio Pacheco complementa que a limitação administrativa só pode atingir uma parcela da propriedade, para condicionar o uso e gozo deste direito ao bem-estar e a paz social através de imposições de ordem pública (obrigações de fazer e de não fazer), cuja desobediência pode acarretar ao proprietário a aplicação de sanção administrativa, como multa, interdição ou suspensão de atividade (PACHECO, 2012). Desse modo, evidencia-se que a reserva legal é limitação administrativa verificada para o uso e ocupação da propriedade rural, visando atender à função social, conforme determina o art. 524 do Código Civil. ${ }^{4}$

Verifica-se que a reserva legal possui um caráter limitador a atuação da propriedade, com objetivo de proteger o meio ambiente, contudo, as recentes alterações trazidas pelo atual Código Florestal deixaram margem de dúvida para aplicação da averbação ou não reserva legal. Tal fato está disposto tanto no art. 18 do Código quando aponta que:

Art. 18 A área de Reserva Legal deverá ser registrada no órgão ambiental competente
por meio de inscrição no CAR de que trata o art. 29 , sendo vedada a alteração de sua
destinação, nos casos de transmissão, a qualquer título, ou de desmembramento, com
as exceções previstas nesta Lei.
$\S 1^{\circ}$ A inscrição da Reserva Legal no CAR será feita mediante a apresentação de planta
e memorial descritivo, contendo a indicação das coordenadas geográficas com pelo
menos um ponto de amarração, conforme ato do Chefe do Poder Executivo.
$\S 2^{\circ}$ Na posse, a área de Reserva Legal é assegurada por termo de compromisso
firmado pelo possuidor com o órgão competente do Sisnama, com força de título
executivo extrajudicial, que explicite, no mínimo, a localização da área de Reserva
Legal e as obrigações assumidas pelo possuidor por força do previsto nesta Lei.
$\S 3^{\circ}$ A transferência da posse implica a sub-rogação das obrigações assumidas no
termo de compromisso de que trata o $\S 2^{\circ}$.

\footnotetext{
${ }^{4}$ Art. 524. A lei assegura ao proprietário o direito de usar, gozar e dispor de seus bens, e de reavê-los do poder de quem quer que injustamente os possua".
}

Rev. de Direito Ambiental e Socioambientalismo | e-ISSN: 2525-9628 | Maranhão | v. 3 | n. 2 | p. 1 - 21 | Jul/Dez. 2017 
$\S 4^{\circ}$ O registro da Reserva Legal no CAR desobriga a averbação no Cartório de Registro de Imóveis, sendo que, no período entre a data da publicação desta Lei e o registro no CAR, o proprietário ou possuidor rural que desejar fazer a averbação terá direito à gratuidade deste ato) (BRASIL, 2012) (grifou-se).

Observa-se que, o art. 18 do atual Código Florestal em seu caput obriga o registro da reserva legal no CAR, Cadastro Ambiental Rural. Antes de adentrar a exposição dos posicionamentos jurisprudenciais acerca do impasse gerado pelo art. 18 (caput e $\S 4^{\circ}$ ), é importante destacar que o CAR foi implantado em 6 de maio de 2014 (art. 21 do Decreto Federal 7.830/2012 e art. 64 da Instrução Normativa do Ministério do Meio Ambiente 2/2014). De acordo com o Ministério do Meio Ambiente:

\begin{abstract}
CAR é o instrumento fundamental para auxiliar o processo de regularização ambiental de propriedades e posses rurais. Consiste no levantamento de informações georeferenciadas do imóvel, com delimitação das áreas de proteção permanente (APP), reserva legal (RL), remanescentes de vegetação nativa, área rural consolidada, áreas de interesse social e de utilidade pública, com o objetivo de traçar um mapa digital a partir do qual são calculados os valores das áreas para diagnóstico ambiental (MMA, 2012, p.1).
\end{abstract}

Neste aspecto, Servinskas (2014, p. 570) aponta que o Cadastro Ambiental Rural - CAR “será obrigatório para todos os imóveis rurais, com a finalidade de integrar informações ambientais das propriedades e posses rurais, compondo base de dados para controle, monitoramento, planejamento ambiental e econômico e combate ao desmatamento".

Observa-se que, o art. 18 do atual Código Florestal em seu caput obriga o registro da reserva legal no CAR, Cadastro Ambiental Rural, e, ao mesmo tempo no $\S 4^{\circ}$ desobriga a averbação no Cartório de Registro de Imóveis. Essa alteração legislativa fez nascer uma das maiores discussões existentes nos tribunais e na doutrina em matéria ambiental na atualidade, a obrigatoriedade ou faculdade na averbação de reserva legal, tento em vista a vigência do atual Código Florestal. Essa discussão está presente no Tribunal de Justiça de Minas Gerais, sendo este o campo de pesquisa para a análise do problema aqui exposto. É o que se passa a analisar. 


\section{DOS POSICIONAMENTOS JURÍDICOS EXISTENTES: APRESENTAÇÃO PRÉVIA DOS ARGUMENTOS PRESENTES NAS TESES JURÍDICAS DO TRIBUNAL PESQUISADO}

Este tópico do trabalho tem objetivo de analisar os posicionamentos existentes no Tribunal de Justiça de Minas Gerais - TJMG em relação às alterações trazidas pelo art. 18 do atual Código Florestal. O primeiro posicionamento aponta para a obrigatoriedade de averbação de reversa legal após o advento do atual Código Florestal (Lei n. 12.651/2012). Já o segundo define que as alterações não extinguiram a obrigação de registro da reserva legal, passando na verdade, a admitir a averbação em outras circunstancias (registro no CAR) e não mais à margem da matrícula do imóvel. Observa-se que os posicionamentos apontados aqui têm como discussão maior a verificação da obrigatoriedade ou faculdade na averbação de reversa legal, após a promulgação do atual Código Florestal.

O primeiro posicionamento aponta para obrigatoriedade na averbação da reserva legal junto ao Cartório de Registro de Imóveis. Observa-se que neste sentido está o entendimento da $1^{a}$ Vogal, Em. Des. Angela de Lourdes Rodrigues, em que a nova legislação ambiental não extinguiu a obrigação de registro da reserva legal. Assim, a Desembargadora decidiu pela manutenção da obrigatoriedade da averbação da reserva legal.

AÇÃO CIVIL PÚBLICA - DIREITO AMBIENTAL - MINISTÉRIO PÚBLICO OBRIGAÇÃO DE INSTITUIÇÃO DE RESERVA LEGAL - NOVO CÓDIGO FLORESTAL - LEI No 12.651/2012 - MANUTENÇÃO DA OBRIGATORIEDADE - AVERBAÇÃO JUNTO AO CADASTRO AMBIENTAL RURAL/CAR INSTRUÇÃO NORMATIVA Nº 2/MMA, DE 06/05/2014 - FIXAÇÃO DO PRAZO DE 01 (UM) ANO PARA INSTITUIÇÃO DE ÁREA DE RESERVALEGAL - NÃO EXAURIMENTO DO REFERIDO PRAZO - IMPROCEDÊNCIA MANTIDA. - $\underline{A}$ Lei $\mathrm{n}^{\circ} 12.651 / 2012$, ainda que tenha revogado a Lei $n$. 4.771/1965, não extinguiu a obrigatoriedade de instituição da área de reserva legal nos imóveis rurais, nem mesmo dispensou o seu registro. - Segundo o novo Código Florestal - Lei no 12.651 de 2012 -, que entrou em vigor durante a tramitação do feito, a área de Reserva Legal deverá ser registrada não mais junto ao Cartório de Registro de Imóveis, mas perante o órgão ambiental competente por meio de inscrição no Cadastro Ambiental Rural/CAR. - Durante a tramitação do feito entrou em vigor o novo Código Florestal, que garantiu a obrigatoriedade de criação de reserva legal e sua averbação somente junto ao Cadastro Ambiental Rural/CAR, eximindo os proprietários rurais do registro na matrícula do imóvel. O CAR só foi implantado pela Instrução Normativa $\mathrm{n}^{\circ}$ 2/MMA, de 06 de maio de 2014, contudo, a regra inserta no art. $5^{\circ}$, $\S 2^{\circ}$ do Decreto $n$. 7.890/12, dispôs que os proprietários de imóveis rurais contam com o período de 1 (um) ano para regularizarem situações pendentes quanto à reserva de área de preservação legal, ou seja, até 06 de maio de 2015. Não tendo exaurido o prazo de que trata o art. $5^{\circ}, \S 2^{\circ}$ do Decreto n. 7.890/12 para que os proprietários do imóvel rural instituam e promovam a averbação da área de reserva legal, não resta configurada a mora no cumprimento das obrigações previstas em lei. (AP CÍVEL/REM

Rev. de Direito Ambiental e Socioambientalismo | e-ISSN: 2525-9628 | Maranhão | v. 3 | n. 2 | p. 1 - 21 | Jul/Dez. 2017 


\title{
A AVERBAÇÃO DE RESERVA LEGAL NO ATUAL CÓDIGO FLORESTAL (LEI № 12.651/2012): UMA ANÁLISE DA JURISPRUDÊNCIA MINEIRA
}

NECESSÁRIA No 1.0702.12.028049-1/001. Rel. Des. Angela de Lourdes Rodrigues. Data de julgamento: 24-04-2017. Data da publicação: 10-07-2017) (Grifo e negrito).

O Des. Carlos Roberto de Faria (também da $8^{\mathrm{a}}$ Câmara Cível do TJMG), sustenta que superveniência da Lei $\mathrm{n}^{\mathrm{o}}$ 12.651, de 2012, que instituiu o atual Código Florestal, não compromete a tese jurídica de obrigatoriedade de averbação da reserva legal, porquanto não supera o dever do proprietário de averbar a reserva legal correspondente a vinte por cento da área do imóvel rural:

\begin{abstract}
APELAÇÃO CÍVEL. AMBIENTAL. AÇÃO CIVIL PÚBLICA. AVERBAÇÃO DE RESERVA LEGAL. IMÓVEL RURAL. SUPERVENIÊNCIA DO NOVO CÓDIGO FLORESTAL. EXIGÊNCIA MANTIDA. FALTA DE INTERESSE DE AGIR. AFASTADO. TEORIA DA CAUSA MADURA. APLICABILIDADE. EXAME DO MÉRITO. 1. Amparado no art. 1.013, $\$ 3^{\circ}$, I, do novo Código de Processo Civil, o Tribunal poderá decidir desde logo o mérito se o processo estiver em condições de imediato julgamento e a sentença estiver fundada em um dos incisos do art. 485 do novo CPC.2. A superveniência da Lei $\mathrm{n}^{\circ} 12.651$, de 2012, que instituiu o novo Código Florestal, não supera o dever do proprietário de averbar a reserva legal correspondente a vinte por cento da área do imóvel rural.3. Na verdade, o novo Código Florestal inovou apenas quanto à forma de cumprimento da obrigação, dispensando a averbação na matrícula imobiliária em caso de inscrição do imóvel no órgão ambiental competente por meio do registro público eletrônico, o Cadastro Ambiental Rural (CAR).4. A obrigação de averbação da reserva legal junto ao Cartório de Imóveis persiste, para todos os efeitos, ao menos enquanto não houver prova do regular registro junto ao Cadastro Ambiental Rural (CAR). (APELAÇÃO CÍVEL N ${ }^{\circ}$ 1.0701.13.008097-4/001. Rel. Des. Carlos Roberto de Faria. Data de julgamento: 0505-2016. Data da publicação: 16-05-2016) (Grifo).
\end{abstract}

Outro posicionamento apresentado na defesa dessa tese jurídica é que a Lei $\mathrm{n}^{\circ}$ 12.651/2012, apesar de ter revogado a Lei $\mathrm{n}^{\circ} 4.771 / 1965$, não extinguiu a obrigatoriedade de instituição da área de reserva legal nos imóveis rurais:

\begin{abstract}
APELAÇÃO CÍVEL - EMBARGOS À EXECUÇÃO - DIREITO AMBIENTAL CUMPRIMENTO DE TERMO DE AJUSTAMENTO DE CONDUTA AVERBAÇÃO DE RESERVA LEGAL - SUPERVENIÊNCIA DO NOVO CÓDIGO FLORESTAL - MANUTENÇÃO DA OBRIGATORIEDADE DA INSTITUIÇÃO DA RESERVA LEGAL - AVERBAÇÃO NO REGISTRO DE IMÓVEIS DISPENSA, NA HIPÓTESE DE EFETIVAÇÃO DA INSCRIÇÃO NO CAR RECURSO PROVIDO. - A Lei $\mathrm{n}^{\circ} 12.651 / 2012$, apesar de ter revogado a Lei $\mathrm{n}^{\circ}$ 4.771/1965, não extinguiu a obrigatoriedade de instituição da área de reserva legal nos imóveis rurais. - O art. 18 da Lei n. 12.651/2012, em seu parágrafo $4^{\circ}$, permite concluir que somente é dispensada a averbação na matrícula do imóvel se já houver o registro no Cadastro Ambiental Rural. - Em assim sendo não promovido o registro do imóvel no CAR, permanece a exigência de averbação da área de reserva legal na matrícula do imóvel. - Recurso a que se dá provimento. (APELAÇÃO CÍVEL No 1.0701.14.039190-8/001. Rel. Des. Luís Carlos Cambogi. Data de julgamento: 11-052017. Data da publicação: 23-05-2017) (Grifo).
\end{abstract}

Rev. de Direito Ambiental e Socioambientalismo | e-ISSN: 2525-9628 | Maranhão | v. 3 | n. 2 | p. 1 - 21 | Jul/Dez. 2017 
Tal corrente, entende que a nova legislação ambiental não extinguiu a obrigação de averbação da reserva legal, ou seja, apenas passou a admitir a possibilidade de afastar a exigência quando realizado o registro no CAR, iniciativa que caberia ao proprietário. Pois caso o proprietário não realize o registro no CAR permanece a obrigação de registro no Cartório de Registro de Imóveis, ou seja, o registro permanece obrigatório.

O segundo posicionamento jurisprudencial em estudo traz que o atual Código Florestal definiu mera faculdade do proprietário a averbação perante o Cartório de Registro de Imóveis, não podendo ser imposta coercitivamente pela via judicial, conforme salientado pelo Eminente Relator Edgard Penna Amorim:

RECURSO DE APELAÇÃO - AÇÃO CIVIL PÚBLICA - RESERVA LEGAL PRELIMINARES - IMPOSSIBILIDADE JURÍDICA DO PEDIDO - FALTA DE INTERESSE PROCESSUAL - REJEIÇÃO - LITISCONSÓRCIO PASSIVO NECESSÁRIO - IEF-MG - INOCORRÊNCIA - AVERBAÇÃO À MARGEM DA MATRÍCULA DO IMÓVEL - DESNECESSIDADE - INSTITUIÇÃO DO CADASTRO AMBIENTAL RURAL - IMPROCEDÊNCIA DO PEDIDO. 1. Em ação civil pública ajuizada com o intuito de obrigar o proprietário a averbar a reserva legal, não há falar em litisconsórcio passivo necessário do Instituto Estadual de Florestas, ainda que a pretensão considere a aprovação administrativa da autarquia no momento de implementação da obrigação. 2. O Novo Código Florestal alterou a forma de se regularizar e dar publicidade ao ato de instituição de reserva legal, que agora se concretiza através da inscrição no CAR - Cadastro Ambiental Rural, registro público de âmbito nacional (art.29), constituindo mera faculdade conferida ao proprietário a averbação perante o registro de imóveis, que, por isso, não mais pode ser imposta coercitivamente pela via judicial. (grifou-se) V.V.: Verificado, à luz do $\S 4^{\circ}$ do art. 18 da novel Lei Federal n. ${ }^{\circ} 12.651 / 2012$, que a dispensa da averbação da reserva legal no Cartório de Registro de Imóveis depende da inscrição da área no Cadastro Ambiental Rural - CAR, não há falar em insubsistência daquela obrigação sem a prova da referida inscrição. ( APELAÇÃO CÍVEL No 1.0702.12.018723-3/001. Rel. Des. Edgar Penna Amorim. Data de julgamento: 10/03/2016. Data da publicação: 23/05/2016.

Ponderou que em caso análogo, o Eminente Relator Des. Paulo Balbino decidiu que se não existe obrigação de averbação da Reserva Legal em Cartórios de Registro de Imóveis, não tem razão a imposição em outros meios para coagir o proprietário a realizar, como nos casos de Termo de Ajuste de Conduta celebrado entre o Ministério Público. Veja a decisão:

APELAÇÃO CÍVEL - EMBARGOS À EXECUÇÃO - TERMO DE AJUSTE DE CONDUTA - RESERVA LEGAL - REGISTRO DE IMÓVEIS - AVERBAÇÃO NOVO CÓDIGO FLORESTAL - OBRIGAÇÃO AFASTADA - MULTA COMINATÓRIA - INEXIGIBILIDADE - DIREITO ADQUIRIDO - OFENSA NÃO CARACTERIZADA. - Se a atual legislação que disciplina o instituto da Reserva Legal não obriga a sua averbação no Ofício do Registro de Imóveis, não tem razão de ser a imposição neste sentido constante do Termo de Ajuste de Conduta celebrado entre o Ministério Público e os proprietários do imóvel rural, tampouco se mostrando exigível a multa cominatória nele ajustada. - Convencionando as partes que a nova

Rev. de Direito Ambiental e Socioambientalismo | e-ISSN: 2525-9628 | Maranhão | v. 3 | n. 2 | p. 1- 21 | Jul/Dez. 2017 


\title{
A AVERBAÇÃO DE RESERVA LEGAL NO ATUAL CÓDIGO FLORESTAL (LEI № 12.651/2012): UMA ANÁLISE DA JURISPRUDÊNCIA MINEIRA
}

legislação que viesse a regular a matéria terá incidência imediata às obrigações assumidas no ajuste, não se acolhe a tese de ofensa a direito adquirido. (APELAÇÃO CÍVEL N ${ }^{\circ}$ 1.0701.14.020164-4/001. Rel. Des. Paulo Balbino. Data de julgamento: 16/03/2016. Data da publicação: 15/04/2016) (Grifo)

Esse também foi o entendimento do voto de relatoria da Eminente Des. Teresa Cristina da Cunha Peixoto que considerou que com o Código Florestal, o CAR tornou-se o registro público de âmbito nacional, não mais tendo a obrigação de averbação junto ao registro de imóveis. Assim, nem o poder judiciário poderá exigir essa obrigação ao proprietário, veja a redação do voto:

\begin{abstract}
REEXAME NECESSÁRIO - ART. 19, LEI DE AÇÃO POPULAR - ANALOGIA APELAÇÃO CÍVEL - AÇÃO CIVIL PÚBLICA - RESERVA LEGAL AVERBAÇÃO À MARGEM DA MATRÍCULA DO IMÓVEL DESNECESSIDADE - INSTITUIÇÃO DO CADASTRO AMBIENTAL RURAL IMPROCEDÊNCIA DO PEDIDO. 1. O Novo Código Florestal alterou a forma de se regularizar e dar publicidade ao ato de instituição de reserva legal, que agora se concretiza através da inscrição no CAR - Cadastro Ambiental Rural, registro público de âmbito nacional (art.29), constituindo mera faculdade conferida ao proprietário a averbação junto ao registro de imóveis, que, por isso, não mais pode ser imposta coercitivamente pela via judicial, o que torna ausente o interesse processual do órgão ministerial quanto a este aspecto. 2. Sentença confirmada, no reexame necessário. Recurso de apelação prejudicado. (APELAÇÃ̃ CÍVEL No 1.0701.12.042695-5/002. Rel. Des. Teresa Cristina da cunha Peixoto. Data de julgamento: 28/04/2016. Data da publicação: 06/05/2016) (Grifo).
\end{abstract}

Ou seja, já havendo registro público próprio, o CAR, e este estando devidamente implantado, como no caso do tribunal ora analisado, observa-se que ser desnecessária a obrigação de averbação, sendo mera faculdade.

APELAÇÃO CÍVEL - AÇÃO CIVIL PÚBLICA - DANO AMBIENTAL PROPRIEDADE RURAL - AVERBAÇÃO DE ÁREA DE RESERVA LEGAL NO REGISTRO DO IMÓVEL - NOVO CÓDIGO FLORESTAL - ATO FACULTATIVO - CADASTRO AMBIENTAL RURAL (CAR) - IMPLANTAÇÃO NO ESTADO DE MINAS GERAIS - PRAZO LEGAL DE UM ANO PARA REGISTRO E INSCRIÇÃO - NÃO ESCOAMENTO - IMPOSSIBILIDADE DE COERÇÃO JUDICIAL - FALTA DE INTERESSE DE AGIR - MATÉRIA DE ORDEM PÚBLICA - REFORMA DA SENTENÇA - APELAÇÃO PREJUDICADA. 1. Conforme dispõe o novo Código Florestal, a área de reserva legal deve ser inscrita no Cadastro Ambiental Rural (CAR), dispondo o proprietário do prazo de um ano, prorrogável por igual período, para a realização do ato de registro no órgão Municipal ou Estadual competente. 2. Já tendo sido implantado o CAR no Estado de Minas Gerais, de responsabilidade da Secretaria Estadual de Meio Ambiente e Desenvolvimento Sustentável, descabe obrigar o proprietário rural, pela via judicial, a averbar a área de reserva legal no registro do imóvel, ato que se tornou facultativo com o novo Código Florestal, notadamente quando ainda não esgotado o prazo legal para inscrição no sistema. 3. Inexistindo nos autos prova de que os requeridos utilizam recursos hídricos nos termos do artigo $1^{\circ}$ da Resolução CONAMA 237, de 1997 e artigo 18 da Lei Estadual 13.199, de 1999, não há falar em licenciamento e outorga

Rev. de Direito Ambiental e Socioambientalismo | e-ISSN: 2525-9628 | Maranhão | v. 3 | n. 2 | p. 1 - 21 | Jul/Dez. 2017 
para o uso de recurso hídrico. 4. Tratando-se de uma das condições da ação, o interesse de agir é matéria de ordem pública, que poderá ser apreciada em qualquer grau de jurisdição, inclusive de ofício. (Des. MR) (APELAÇÃO CÍVEL No 1.0702.11.042021-4/00. Rel. Des. Afrânio Vilela. Data de julgamento: 14/07/2016. Data da publicação: 20/07/2016) (Grifo).

A teor do art. 18 da Lei 7.347/85, a condenação do Ministério Público ao pagamento de honorários advocatícios nas ações civis públicas somente é possível nas hipóteses de comprovada má-fé." (Apelação Cível No 1.0701.12.043010-6/001 - COMARCA DE Uberaba. Rel. Des. Gilson Soares Lemes. Data de julgamento: 25-08-2016. Data da publicação: 06-092016

Portanto, esse segundo posicionamento da jurisprudência entende que a nova legislação desobriga a averbação no Cartório de Registro de Imóveis, conforme destaca-se mais algumas decisões do Egrégio Tribunal de Justiça de Minas Gerais:

Reexame necessário - Apelação cível - Embargos à execução - dano ambiental propriedade rural - averbação de área de reserva legal no registro do imóvel - novo Código Florestal - ato facultativo - Cadastro Ambiental Rural (CAR) - implantação no Estado de Minas Gerais - prazo legal de um ano para registro e inscrição - não escoamento - TAC - multa moratória - título inexigível - sentença confirmada. 1 Conforme dispõe o novo Código Florestal, a área de reserva legal deve ser inscrita no Cadastro Ambiental Rural (CAR), dispondo o proprietário do prazo de um ano, prorrogável por igual período, para a realização do ato de registro no órgão Municipal ou Estadual competente. 2 - Já tendo sido implantado o CAR no Estado de Minas Gerais, de responsabilidade da Secretaria Estadual de Meio Ambiente e Desenvolvimento Sustentável, descabe obrigar o proprietário rural a averbar a área de reserva legal no registro do imóvel, ato que se tornou facultativo com o novo Código Florestal, notadamente quando ainda não esgotado o prazo legal para inscrição no sistema, sendo inexigível multa moratória firmada em TAC junto ao Ministério Público. (APELAÇÃO CÍVEL No 1.0701.14.021209-6/001. Rel. Des. Marcelo Rodrigues. Data de julgamento: 17/052016. Data de publicação: 25/05/2016) (grifouse)

V.V. APELAÇÃO CÍVEL - AÇÃO CIVIL PÚBLICA - AVERBAÇÃO DA RESERVA LEGAL À MARGEM DA MATRÍCULA DO IMÓVEL RURAL - FATO OCORRIDO NA VIGÊNCIA DA LEI 4.771/75 - NOVO CÓDIGO FLORESTAL (LEI 12.651/12) - ART.462- INAPLICABILIDADE - APLICAÇÃO DO PRINCÍPIO DA IRRETROATIVIDADE - SENTENÇA QUE DETERMINA INSTITUIÇÃO DE RESERVA LEGAL E REGISTRO NO CAR - AUSÊNCIA DE IRRESIGNAÇÃO DO MINISTÉRIO PÚBLICO - IMPOSSIBILIDADE DE MODIFICAÇÃO FIXAÇÃO DE ASTREINTES - POSSIBILIDADE - COISA JULGADA MATERIAL - INOCORRÊNCIA - MODIFICAÇÃO DE ACORDO COM O CASO CONCRETO - SENTENÇA MANTIDA. 1. Por força do princípio da irretroatividade legal, o Novo Código Florestal (Lei no 12.651/12) não se aplica ao fato ocorrido sob o diploma revogado (Lei 4.771/75) e, por se tratar de direito superveniente, incabível invocar os ditames do artigo 462 do CPC para este fim. 2. A averbação de reserva legal de propriedade rural cuja aquisição é anterior à entrada em vigor do Novo Código Florestal deve observar os ditames da lei em vigor ao tempo do fato. 3. Determinando o sentenciante a instituição da reserva legal segundo os ditames do Novo Código Floresta (art. 18) com o registro no CAR, inexistindo irresignação do

Rev. de Direito Ambiental e Socioambientalismo | e-ISSN: 2525-9628 | Maranhão | v. 3 | n. 2 | p. 1 - 21 | Jul/Dez. 2017 
Ministério Público, deve ser mantida a sentença. 4. A fixação de astreintes, por não fazer coisa julgada material, pode ser revista se o cumprimento da obrigação se tornar impossível em razão da conduta de terceiros, especialmente do IEF, devendo o réu comprovar as dificuldades enfrentadas ao juízo da execução, que avaliará se houve omissão do executado ou absoluta impossibilidade de cumprimento da obrigação por ato de terceiro. (Des. AV) (APELAÇÃO CÍVEL No 1.0702.11.042021-4/001. Rel. Des. Afrânio Vilela. Data de julgamento: 14/07/2015. Data da publicação: 20/07/2015)

Como se pode observar, no tribunal pesquisa do existem 02 (dois) posicionamentos em relação ao tema ora estudado. O primeiro posicionamento aponta para obrigatoriedade na averbação da reserva legal junto ao Cartório de Registro de Imóveis, tendo como base argumentativa o fato de que a atual legislação ambiental não extinguiu a obrigação de registro da reserva legal, principalmente devido o teor principiológico do direito ambiental. Já o segundo posicionamento considera ser facultativo a obrigação do proprietário de averbação perante o Cartório de Registro de Imóveis.

Diante dessa divergência existente na aplicação da atual legislação ambiental é importante destacar alguns pontos em relação a cada um dos posicionamentos e os argumentos consolidados para tais posições. Sendo que o próximo passo deste trabalho será realizar uma análise entre o primeiro posicionamento e sua base argumentativa em relação ao princípio da proibição do retrocesso.

\section{A SUPERAÇÃO DO PRINCÍPIO DA PROIBIÇÃO DE RETROCESSO AMBIENTAL COMO BASE ARGUMENTATIVA DA TESE JURÍDICA DA OBRIGATORIEDADE DE AVERBAÇÃO DE RESERVA LEGAL}

Como visto, o primeiro posicionamento, que mantem a obrigatoriedade de averbação da reserva legal, tem como base argumentativa a necessidade de manutenção do ambiente ecologicamente equilibrado. Para respaldar esse posicionamento, utiliza-se dos princípios do direito ambiental, por ser um direito essencialmente principiológico, para reforçar a base argumentativa da presente posição. Contudo, a análise quanto aplicação do princípio da proibição do retrocesso ambiental não pode ser considerado argumento viável para ponderar a aplicação da manutenção da obrigatoriedade da averbação de reserva legal. Este resultado pode ser justificado pelos apontamentos que se passa a apresentar.

Os princípios desempenham a importante função de conferir unidade normativa a todo sistema jurídico e exercem função fundamentadora, bem como constituem fonte de 
interpretação das regras. Dentre os princípios inerentes ao Direito Ambiental, pode-se destacar: princípio da informação, princípio do direito ao meio ambiente equilibrado, princípio da sustentabilidade, princípio da prevenção (precaução ou cautela), princípio da proteção do retrocesso ambiental e princípio do poluidor pagador.

Dentre todos os princípios apontados acima, o princípio da proibição de retrocesso ambiental, da mesma forma como ocorre com a proibição de retrocesso social, está relacionada ao princípio da segurança jurídica, da proteção da confiança ou mesmo de previsibilidade no enquadramento normativo das relações jurídicas (as garantias constitucionais do direito adquirido, do ato jurídico perfeito e da coisa julgada, bem como os limites das matérias à reforma constitucional são expressão do princípio constitucional da segurança jurídica), o que se apresenta como um traço característico da conformação do Estado de Direito. Neste sentido, Piovesan (2016) destaca que a "proibição do retrocesso social" existe na medida em que é vedado aos Estados retrocederem na implementação de direitos que prejudiquem a sociedade. De outra forma, o que se está a determinar com a proibição de retrocesso é a subordinação do legislador infraconstitucional ao comando normativo constitucional, em respeito ao princípio da supremacia da Constituição. (FENSTERSEIFER, 2008, p. 258).

Muitos autores admitem que devido ao cenário de crise (política, ecológica, econômica, financeira e social) que o mundo está vivendo, o princípio da proibição do retrocesso reacendeu a discussão em torno da admissibilidade ou não, ou seja, aplicação da "proibição do retrocesso", ou da "teoria da irreversibilidade" (BOTELHO, 2015). Em relação a temática ambiental, o arcabouço jurídico brasileiro considera que o princípio da proibição do retrocesso ambiental possui demanda premente da época atual, tendo em vista o dilema desenvolvimento e redução de recursos ambientais (ROLLEMBERG, 2012).

Observa-se que o princípio da proibição do retrocesso ecológico "significa que, afora as mudanças de fatos significativos, não se pode admitir um recuo tal dos níveis de proteção que os leve a serem inferiores aos anteriormente consagrados" (PRIEUR, 2012, p. 38). Ou seja, limita as possibilidades de revisão ou de revogação de normas prejudiciais ao meio ambiente.

Muitos consideram que devido ao princípio ora analisado, a manutenção da obrigação de averbação de reserva legal é fator que deve ser considerado, pois se houvesse faculdade na obrigação de averbação da reserva legal em cartórios, não estariam resguardando o princípio da proibição do retrocesso ambiental.

Rev. de Direito Ambiental e Socioambientalismo | e-ISSN: 2525-9628 | Maranhão | v. 3 | n. 2 | p. 1 - 21 | Jul/Dez. 2017 
Contudo, referido argumento está superado, pois a obrigação de averbação da reserva legal em cartório não foi extinta em totalidade, em verdade o que se realizou foi a alteração do registro público de âmbito nacional definido para cadastro das áreas de reserva legal, que no passado era os cartórios de registro de imóveis e na atualidade é realizado pelo CAR, após a alteração legislativa do Código Florestal. Assim, as alterações trazidas pelo Código não estão prejudicando o princípio da proibição do retrocesso, apenas houve uma alteração da modalidade de registro pelo Estado. Neste sentido, veja a julgado abaixo:

REEXAME NECESSÁRIO - DIREITO AMBIENTAL - AÇÃO CIVIL PÚBLICA AVERBAÇÃO DE ÁREA DE RESERVA LEGAL - NOVO CÓDIGO FLORESTAL - EXIGÊNCIA MANTIDA - OBRIGATORIEDADE DA AVERBAÇÃO NO REGISTRO DE IMÓVEIS OU NO CADASTRO AMBIENTAL RURAL (CAR) PERCENTUAL MÍNIMO DE VINTE POR CENTO. 1 - O cumprimento da obrigação de inscrição do imóvel rural no Cadastro Ambiental Rural, após a propositura da ação, não configura perda do interesse processual; 2 - $\underline{\text { O novo Código }}$ Florestal (Lei Federal $n^{\circ}$ 12.651/12) apenas substituiu a averbação da área de reserva legal na matrícula do imóvel pelo registro da referida área no Cadastro Ambiental Rural (CAR) sem, contudo, extinguir a obrigatoriedade da instituição e da preservação da reserva legal, sendo certo que a edição da nova lei não acarretou em retrocesso socioambiental, por não reduzir a proteção dos direitos ambientais; 3 - O Órgão Especial do Tribunal de Justiça do Estado de Minas Gerais reconheceu a inconstitucionalidade do art. 67 do Novo Código Florestal, que desonerou o dever de restauração da área de Reserva Legal nos imóveis que detinham, até 22 de julho de 2008, área de até 4 (quatro) módulos fiscais (Incidente de Arguição de Inconstitucionalidade $\mathrm{n}^{\mathrm{o}}$ 1.0144.11.003964-7/002, Rel. Des. Walter Luiz, Órgão Especial, DJe 14/08/2015). APELAÇÃO CÍVEL No 1.0479.13.003440-4/001. Rel. Des. Renato Dresch. Data do julgamento: 09-02-2017. Data da publicação: 17-022017) (Grifo).

Como se pode observar, o argumento de aplicação do posicionamento da obrigação de registro em cartório da reserva legal não pode ser considerado com base na aplicação do princípio da proibição do retrocesso ambiental. Afinal de contas, o atual Código apenas substituiu a averbação da área de reserva legal na matrícula do imóvel pelo registro da referida área no Cadastro Ambiental Rural (CAR).

Diante destes fatos, passa-se a análise do posicionamento jurídico considerado viável para aplicação. 


\section{DA FACULdADE DE AVERBAÇÃO DE RESERVA LEGAL COMO TESE JURÍDICA VIÁVEL}

A grande discussão existente neste caso está na aplicação da obrigação ou faculdade para aplicação da averbação de reserva legal em cartório de registro de imóveis. Diante de todo o exposto a tese jurídica que deve prevalecer é da faculdade de averbação de reserva legal. Tal conclusão é considerada tem em vista o disposto no $\S 4^{\circ}$ do art. 18 da Lei n. 12.651/2012 (atual Código Florestal), há a dispensa da averbação da reserva legal no Cartório de Registro de Imóveis. Ponderou que a reserva legal deve agora ser inscrita no Cadastro Ambiental Rural CAR, dispensando-se a averbação perante o Cartório de Registro de Imóveis.

Assim, o atual Código Florestal inova em sua redação ao deixar claro que não prevê a exigência de reserva legal para determinados empreendimentos, que estão previstos no art. 12:

\footnotetext{
$\S 6^{\circ}$ Os empreendimentos de abastecimento público de água e tratamento de esgoto não estão sujeitos à constituição de Reserva Legal.

$\S 7^{\circ}$ Não será exigido Reserva Legal relativa às áreas adquiridas ou desapropriadas por detentor de concessão, permissão ou autorização para exploração de potencial de energia hidráulica, nas quais funcionem empreendimentos de geração de energia elétrica, subestações ou sejam instaladas linhas de transmissão e de distribuição de energia elétrica.

$\S 8^{\circ}$ Não será exigido Reserva Legal relativa às áreas adquiridas ou desapropriadas com o objetivo de implantação e ampliação de capacidade de rodovias e ferrovias.
}

Portanto, a averbação são todas as alterações que ocorrem no registro de um imóvel. Trata-se de um histórico de mudanças realizadas no imóvel, conforme já apontado no tópico 2 deste trabalho. Como já descrito acima, o CAR consiste no levantamento de informações geoferreferenciadas do imóvel, com delimitação das áreas de proteção permanente (APP), reserva legal (RL), remanescentes de vegetação nativa, área rural consolidada, áreas de interesse social e de utilidade pública com o objetivo de traçar um mapa digital a partir do qual são calculados os valores das áreas para diagnóstico ambiental (MMA, 2012).

A Lei n. 12.651, de 25 de maio de 2012 prescreve no art. 12:

Art. 12. Todo imóvel rural deve manter área com cobertura de vegetação nativa, a título de Reserva Legal, sem prejuízo da aplicação das normas sobre as Áreas de Preservação Permanente, observados os seguintes percentuais mínimos em relação à área do imóvel, excetuados os casos previstos no art. 68 desta Lei I - localizado na Amazônia Legal:

a) $80 \%$ (oitenta por cento), no imóvel situado em área de florestas;

b) $35 \%$ (trinta e cinco por cento), no imóvel situado em área de cerrado;

c) $20 \%$ (vinte por cento), no imóvel situado em área de campos gerais;

Rev. de Direito Ambiental e Socioambientalismo | e-ISSN: 2525-9628 | Maranhão | v. 3 | n. 2 | p. 1- 21 | Jul/Dez. 2017 


\title{
A AVERBAÇÃO DE RESERVA LEGAL NO ATUAL CÓDIGO FLORESTAL (LEI № 12.651/2012): UMA ANÁLISE DA JURISPRUDÊNCIA MINEIRA
}

II - localizado nas demais regiões do País: 20\% (vinte por cento).

De acordo com o dispositivo acima é aplicado a todas as propriedades, tendo em vista que a lei menciona o percentual de $20 \%$ (vinte por cento) de cada propriedade.

Em consonância com o atual Código Florestal, a área de reserva legal deve ser inscrita no Cadastro Ambiental Rural (CAR), dispondo o proprietário do prazo de um ano, prorrogável por igual período, para a realização do ato de registro no órgão Municipal ou Estadual competente 5 . Portanto, de acordo com o atual Código Florestal há a faculdade para o proprietário rural e não uma obrigação.

Fundamentou no artigo 29 do atual Código Florestal:

É criado o Cadastro Ambiental Rural - CAR, no âmbito do Sistema Nacional de Informação sobre o Meio Ambiente - SINIMA, registro Público eletrônico de âmbito nacional, obrigatório para todos os imóveis rurais. Com finalidade de integrar as informações ambientais das propriedades e posses rurais, compondo base de dados para controle, monitoramento, planejamento ambiental e econômico e combate ao desmatamento.

Destacou ainda o art. 18 dessa mesma legislação:

\begin{abstract}
A área de reserva legal deverá ser registrada no órgão ambiental competente, por meio da inscrição no CAR de que trata o art. 29 , sendo vedada a alteração de sua destinação, nos casos de transmissão, a qualquer título, ou de desmembramento, com as exceções previstas nessa lei.

$\S 1^{\circ}$. A inscrição da reserva legal no CAR será feita mediante a apresentação de planta e memorial descritivo contendo a indicação das coordenadas geográficas, com pelo menos um ponto de amarração, conforme ato do Chefe do Poder executivo.

$\S 4^{\circ}$. O registro da reserva legal desobriga a averbação no Cartório de Registro de Imóveis.
\end{abstract}

Neste sentido, destacou o Eminente Relator Gilson Soares Lemes nos autos de sua relatoria acima ementado, que com a publicação do atual Código Florestal (Lei nº 12.651/2012), a obrigatoriedade da averbação da reserva legal em Cartório de Registro de Imóveis (CRI) não mais existe. Veja:

APELAÇÃO CÍVEL. DIREITO AMBIENTAL. AÇÃO CIVIL PÚBLICA. TERRENO RURAL. RESERVA LEGAL. ABERBAÇÃO NO CARTÓRIO DE REGISTRO DE IMÓVEIS. FACULDADE. INSTITUIÇÃO DO CADASTRO AMBIENTAL RURAL/CAR. LICENCIAMENTO AMBIENTAL E RECURSOS

\footnotetext{
${ }^{5}$ Nesse sentido: a inscrição no CAR será obrigatória para todas as propriedades e posses rurais, devendo ser requerida no prazo de 1 ąno da sua implantação, prorrogável uma única vez, por igual período, por ato do chefe do Poder Executivo (art. 29 e seus paragrafos da Lei n. 12. 651-2012). (SERVINSKAS, 2012, p. 571)
}

Rev. de Direito Ambiental e Socioambientalismo | e-ISSN: 2525-9628 | Maranhão | v. 3 | n. 2 | p. 1 - 21 | Jul/Dez. 2017 
HÍDRICOS. NÃO COMPROVAÇÃO. HONORÁRIOS ADVOCATÍCIOS. MINISTÉRIO PÚBLICO. DESCABIMENTO.

Em consonância com o $\S 4^{\circ}$ do art. 18 da Lei n. 12.651/2012, com redação dada pela Lei n. 12.727 de 2012, a reserva legal deve ser registrada no Cadastro Ambiental Rural - CAR, constituindo uma faculdade a averbação perante o Cartório de Registro de Imóveis.

Se não há prova nos autos que os requeridos desenvolvam atividades que demandem licenciamento ambiental ou façam uso de recursos hídricos em sua propriedade, o desprovimento, nesse aspecto, é a medida que se impõe.

A teor do art. 18 da Lei 7.347/85, a condenação do Ministério Público ao pagamento de honorários advocatícios nas ações civis públicas somente é possível nas hipóteses de comprovada má-fé ( Apelação Cível No 1.0701.12.043010-6/001 - COMARCA DE Uberaba. Rel. Des. Gilson Soares Lemes. Data de julgamento: 25-08-2016. Data da publicação: 06-09-2016.)

Esse também é o posicionamento de parte da doutrina, como aponta Gilmara Vanderlinde Medeiros D’Avila que define que:

Conforme dispõe a Lei n. 12.651/12, que criou o CAR, a averbação da reserva legal junto a matrícula imobiliária, no Registro de Imóveis, tornou-se facultativa, quando a mesma já estiver registrada no Cadastro Ambiental Rural (CAR). Ocorre que não foi implementado, em vários Estados, o Cadastro Ambiental Rural, de modo que, nesses Estados, a obrigação de averbação na matrícula do imóvel se mantém. O novo Código Florestal desobriga a averbação no Cartório de Registro de Imóveis apenas se for registrada a Reserva Legal no CAR. Logo, ausente no respectivo Estado, devem os interessados cumprir o encargo de averbar a reserva. (D'ÁVILA, 2015, p. 358) (grifo)

Concluiu que, em consonância com o $§ 4^{\circ}$ do art. 18 da Lei n. 12.651/2012, há a dispensa da averbação da reserva legal no Cartório de Registro de Imóveis, sendo este o posicionamento jurídico viável a aplicação. Ponderou que a reserva legal deve agora ser inscrita no Cadastro Ambiental Rural - CAR, dispensando-se a averbação perante o Cartório de Registro de Imóveis.

\section{CONCLUSÃO}

Restou demonstrado que a reserva legal constitui um instrumento de grande relevância na manutenção da qualidade de vida e do equilíbrio ecológico. Com o advento do atual Código Florestal verificou-se que há divergência acerca da obrigatoriedade da averbação da reserva legal no Cartório de Registro de Imóveis.

Uma corrente entende que a nova legislação ambiental não extinguiu a obrigação de averbação da reserva legal, já a outra parte do pressuposto que constitui mera faculdade do proprietário a averbação perante o Cartório de Registro de Imóveis, não podendo ser imposta

Rev. de Direito Ambiental e Socioambientalismo | e-ISSN: 2525-9628 | Maranhão | v. 3 | n. 2 | p. 1 - 21 | Jul/Dez. 2017 
coercitivamente pela via judicial. Destacou-se que reserva legal a partir da nova legislação, deve ser inscrita no Cadastro Ambiental Rural - CAR, dispensando-se a averbação perante o Cartório de Registro de Imóveis.

Restou demonstrado que de acordo com o $\S 4^{\circ}$ do art. 18 da Lei n. 12.651/2012, há a dispensa da averbação da reserva legal no Cartório de Registro de Imóveis. Esse é o posicionamento viável de aplicação e também o que acolhemos.

\section{REFERÊNCIAS}

ANTUNES, Paulo de Bessa. Direito ambiental. 12. ed. amplamente reformulada. Rio de Janeiro: Lumen Juris, 2010. 16 ed. 2014.

BOTELHO, Catarina Santos. Os direitos sociais num contexto de austeridade: um elogio fúnebre ao princípio da proibição do retrocesso social? (Social Rights in a Context of Austerity: An Eulogy to the Principle of the Prohibition of Social Retrogression?) 2015. Revista da Ordem dos Advogados, v. I/II, pp. 259-294, 2015. Disponível em: <https://ssrn.com/abstract=2911142>. Acesso em: 28 jun. 2017.

BRASIL. Lei $n^{\circ} 12.651$, de 25 de maio de 2012. Dispõe sobre a proteção da vegetação nativa; altera as Leis nos 6.938, de 31 de agosto de 1981, 9.393, de 19 de dezembro de 1996, e 11.428, de 22 de dezembro de 2006; revoga as Leis nos 4.771, de 15 de setembro de 1965, e 7.754, de 14 de abril de 1989, e a Medida Provisória no 2.166-67, de 24 de agosto de 2001; e dá outras providências. Planalto. Disponível em:

<http://www.planalto.gov.br/ccivil_03/_ato2011-2014/2012/lei/112651.htm>. Acesso em: 28 jun. 2017.

CANOTILHO, José Joaquim Gomes; LEITE, José Rubens Morato (Coords.). Direito constitucional ambiental brasileiro. São Paulo: Saraiva, 2007.

D’ÁVILA, Gilmara Vanderlinde Medeiros. Averbação da reserva legal x Cadastro ambiental rural, avanço ou retrocesso? Revista Eletrônica Direito e Política, Programa de PósGraduação Stricto Sensu em Ciência Jurídica da UNIVALI, Itajaí, v.10, n.1, 2015.

DI PIETRO, Maria Sylvia Zanella, Direito administrativo. 8. Ed. São Paulo: Atlas, 1997.

FENSTERSEIFER, Tiago. Direitos fundamentais e proteção do ambiente: a dimensão ecológica da dignidade humana no marco jurídico constitucional do estado socioambiental de direito. 2008.

FIORILLO, Celso Antônio. Curso de direito ambiental brasileiro. São Paulo: Saraiva, 2000.

FREITAS, Juarez. Sustentabilidade: direito ao futuro. Belo Horizonte: Fórum, 2011.

Rev. de Direito Ambiental e Socioambientalismo | e-ISSN: 2525-9628 | Maranhão | v. 3 | n. 2 | p. 1 - 21 | Jul/Dez. 2017 
FURLAN, Anderson; FRACALOSSI, Willian. Direito ambiental. Rio de Janeiro: Forense, 2010.

MACHADO, Paulo Affonso Leme. Direito Ambiental brasileiro. 12. ed. rev. atual. e ampl. São Paulo: Malheiros, 2004. 20 ed. 2012.

MACHADO, Paulo Affonso Leme. Estudos de direito ambiental. São Paulo: Malheiros, 1994.

MEIRELLES, Hely Lopes. Direito Administrativo Brasileiro. São Paulo: Malheiros, 2008.

MILARÉ, Edis. Direito administrativo e meio ambiente. 4.ed. São Paulo: Atlas, 2011.

Direito do ambiente; a gestão ambiental em foco; doutrina; jurisprudência;

glossário. 7. ed. rev., atual. e reformulada. São Paulo: Revista dos Tribunais, 2011.

MILARÉ, Edis; MACHADO, Paulo Affonso Leme. Novo código florestal: comentários à Lei 12.651, de 25 de maio de 2012 e à Med Prov 571, de 25 de maio de 2012. São Paulo: Revista dos Tribunais.

MMA. Ministério de Meio Ambiente. Cadastro Ambiental Rural. 2012. Disponível em: <http://www.mma.gov.br/desenvolvimento-rural/cadastro-ambiental-rural >. Acesso em: 28 jun. 2017.

MOARES, Luís Carlos Silva de. Direito Ambiental, São Paulo: Atlas, 2002.

MUKAI, Toshio. Direito ambiental sistematizado. São Paulo: Forense, 1992.

PACHECO, Sérgio. O Novo Código Florestal e a isenção da reserve legal para áreas inundadas pelos reservatórios das hidrelétricas. 2012. Disponível em:

<http://www.abce.org.br/downloads/Artigo\%20RL.pdf>. Acesso em: 28 jun. 2017.

PIOVESAN, Flávia. Direitos humanos e o direito constitucional internacional. 8. ed. São Paulo: Saraiva, 2016, p. 178.

PRIEUR, Michel. Princípio da Proibição de Retrocesso Ambienta - Introdução. In: Comissão de Meio Ambiente, Defesa do Consumidor e Fiscalização e Controle. Princípio da Proibição de Retrocesso Ambiental. Senado Federal. Brasília - DF, 2012. Disponível em:

$<$ http://www2.senado.leg.br/bdsf/bitstream/handle/id/242559/000940398.pdf?sequenc\#page= 8>. Acesso em: 28 jun. 2017.

RASLAN, Alexandre Lima (Org.). Direito ambiental. Campo Grande: UFMS, 2010. ROLLEMBERG, Rodrigo. Apresentação. In: Comissão de Meio Ambiente, Defesa do Consumidor e Fiscalização e Controle. Princípio da Proibição de Retrocesso Ambiental. Senado Federal. Brasília - DF, 2012. Disponível em: <http://www2.senado.leg.br/bdsf/bitstream/handle/id/242559/000940398.pdf?sequenc\#page= 8>. Acesso em: 28 jun. 2017. 
SAMPAIO, José Adércio leite; WOLD, Chris; NARDY, Afrânio. Princípios do direito ambiental. Belo Horizonte: Del Rey, 2003.

SETTE, Maerli T. Deon. Direito ambiental. São Paulo: MP, 2010.

SILVA, Bruno Campos. O licenciamento ambiental único e outros aspectos relevantes da Lei Complementar n. 140-2011. Revista Magister de Direito Ambiental e Urbanístico. V. 01. Ago-set. Porto Alegre: Magister, 2005, p. 05-117.

SILVA, José Afonso da. Direito ambiental constitucional. 2. Ed. São Paulo: Malheiros, 1998.

SIRVINSKAS, Luís Paulo. Manual de direito ambiental. 12. Ed. São Paulo: Saraiva, 2014.

SPITZCOVSKY, Ceslo. Direito Administrativo. 10. ed. São Paulo: Método, 2008.

THOMÉ, Romeu. Manual de direito ambiental. 7. Ed. Salvador: Juspodivm, 2017. 